\title{
FINANCIAL MARKET LEX MERCATORIA AND ITS INFLUENCE ON THE FINANCIAL COLLATERAL DIRECTIVE
}

\section{Ivan Tot*}

\begin{abstract}
Directive 2002/47/EC of the European Parliament and of the Council of 6 June 2002 on financial collateral arrangements ('Financial Collateral Directive') was adopted as a part of the EU legal framework for financial markets in order to enhance the stability of the financial system in the EU. Several of its key provisions dealing with the financial collateral arrangements had required the Member States to introduce new rules in the national legal systems which were substantially different from the existing legal solutions employed in the national property, contract, and insolvency laws. These provisions of Financial Collateral Directive represent a reception of the financial market practice embodied in the various standard master agreements drawn up by the international financial market associations. The level of this reception indicates that the true legislator of the European financial market in the field of financial collateral is the financial market itself. This paper identifies and explores the origins of the provisions of Financial Collateral Directive in the financial market practice and the effects of the Financial Collateral Directive on the national legal systems in the EU.
\end{abstract}

KEYWORDS: Financial Collateral Directive, financial market, financial collateral, financial collateral arrangement, repurchase transaction, repo

\footnotetext{
* Postdoctoral Researcher at Department of Law, Faculty of Economics and Business, University of Zagreb; itot@efzg.hr
} 


\section{INTRODUCTION ${ }^{1}$}

When discussing the emergence of new, non-traditional legal actors in the national and supranational regulatory space and their growing role in the establishing, application and the enforcement of the legal norms, one can find a solid evidence of these new tendencies in the European Union regulatory framework for the European financial markets, which was established under the visible influence of the international financial market associations and of the practices settled between participants on the financial markets. A prime example of a legally binding instrument that was highly impacted by the legal solutions developed in the financial markets, that was adopted in order to address the needs of the financial market participants, and that was aimed at the elimination of the legal obstacles to the integration and cost-efficiency of the European financial markets, is the Financial Collateral Directive. ${ }^{2}$

The objective of the Financial Collateral Directive was to create a minimum EU legal regime for the provision of financial collateral in bilateral financial collateral arrangements. These arrangements are widely used in the financial markets by commercial banks, central banks, investment firms, insurance companies and other financial institutions. The various financial transactions, which rely on the financial collateral arrangements, are typically entered into by the market participants under a master agreement, the purpose of which is to provide a framework under which individual transactions can be concluded and documented. The standard master agreements, prepared and published by the international financial market associations, are available for the most important types of financial transactions.

The recurring financial market-created legal rules contained in these standard master agreements could be seen as part of the "financial market lex mercato$\mathrm{ria}^{3}{ }^{3}$ The effectiveness of these privately created legal norms largely depends

\footnotetext{
1 The paper was presented at INTRAlaw Conference "Law in transition - Interacting legal orders and changing actors" (28 - 29 September 2017, Aarhus University, Department of Law, Aarhus, Denmark). The author is thankful for all the comments received during the discussion after the presentation, especially to Professor Hanne Petersen (University of Copenhagen, Faculty of Law), Dr Soterios Loizou (King's College London) and Dr Tara Van Ho (University of Essex, School of Law and Human Rights Centre).

2 Directive 2002/47/EC of the European Parliament and of the Council of 6 June 2002 on financial collateral arrangements (OJ L 168, 27/6/2002); hereinafter: Financial Collateral Directive.

3 This view was proposed in the literature by Professor Noah Vardi who argues that the concept of lex mercatoria should be extended to comprise the rules applied in international financial transactions; see, in particular: Vardi, N.: The Integration of European Financial Markets, Routledge-Cavendish, London - New York, 2011, pp. 117-121, 160-166. On the sub-
} 
on their compatibility with the state-originated laws. In the field of the law on financial collateral, prior to the adoption of the Financial Collateral Directive, the legal solutions developed in the financial market practice were faced with the legal barriers to the efficient use of financial collateral in cross-border transactions, which were created by the non-harmonized national laws of the EU Member States. Challenged with the legal obstacles to the use of financial collateral arrangements, the financial market participants and their associations became loud advocates for the reform of the European national laws in the area of financial collateral. The industry's needs for legal change were met with the adoption of the Financial Collateral Directive, which brought on a full harmonization of substantive rules regarding the use of financial collateral in financial collateral arrangements.

Financial Collateral Directive is 'a significant instance of a reception, at the legislative level, of rules elaborated by market practice'. ${ }^{4}$ The adoption of the market-originated rules relating to financial collateral arrangements in the Financial Collateral Directive, and consequently in the domestic laws of the EU Member States, is a result of the strong involvement of the financial market participants in the legislative process, which may be seen as 'the successful lobbying for law reform' ${ }^{5}$

The law relating to financial collateral, as a new field of law which is derived from the Financial Collateral Directive, has received a lot of the scholarly attention in the recent years. Several comprehensive works on the various aspects of financial collateral arrangements, and on the Financial Collateral Directive, had been made by academics and legal experts in the field. ${ }^{6}$ With an

ject of financial market lex mercatoria, see also: Collins, H., Flipping Wreck: Lex Mercatoria on the Shoals of Ius Cogens, in Grundmann, S., Möslein, F. and Riesenhuber, K. (eds.), Contract Governance - Dimensions in Law and Interdisciplinary Research, Oxford University Press, Oxford, 2015, pp. 383-406. For an opposing view, which speaks against the emergence of financial lex mercatoria, see: Zimmermann, C. D.: A Contemporary Concept of Monetary Sovereignty, Oxford University Press, Oxford, 2013, pp. 81-83. See also: Cuniberti, G.: Three Theories of Lex Mercatoria, Columbia Journal of Transnational Law, 52 (2) 2014, pp. 377-378.

4 See Vardi, op. cit. (fn. 3), p. 82.

5 See Johansson, E.: Property Rights in Investment Securities and the Doctrine of Specificity, Springer, Berlin - Heidelberg, 2009, p. 10.

6 Especially: ibid.; Keijser, T. R. M. P.: Financial Collateral Arrangements, Kluwer, Deventer, 2006.; Yeowart, G., Parsons, R., Murray, E. and Patrick, H.: Yeowart and Parsons on the Law of Financial Collateral, Edward Elgar Publishing, Cheltenham - Northampton, 2016. Also, see Benjamin, J.: Financial Law, Oxford University Press, Oxford - New York, 2007, pp. 445-481; Gretton, G. L.: Financial Collateral and the Fundamentals of Secured Transactions, Edinburgh Law Review, 10 (2), 2008, pp. 209-238; Murray, E.: Financial collateral arrangements and the financial markets, in Dahan, F. (ed.), Research Handbook on Secured Financing 
aim to identify and explore the connections between the market practice and the regulation of the European financial market in the area of financial collateral, this paper builds on these contributions to provide a non-specialist reader with insights on the selected key issues of the law on financial collateral.

The paper is divided into six chapters. The Chapter 2 of the paper begins with a brief description of the notion and the main features of financial collateral arrangements, and of the methods for the provision of financial collateral under a financial collateral arrangement. Due to existence of the various types of financial transactions which rely on financial collateral arrangements, in addressing the key aspects relevant to the subject of the paper, the paper will narrow its focus on the repurchase transactions or 'repos', which are the most important type of securities financing transactions in the European financial markets. The characteristics and the structure of a repurchase transaction are analyzed in the Chapter 3 of the paper, in which the market standard master agreement, commonly used by market participants when entering into repurchase agreements in the European repo market, is also examined. The Chapter 4 of the paper highlights the main points of involvement of the financial market participants in the legislative process leading to the adoption of the Financial Collateral Directive. This chapter explains how the legal rules of the national laws of the Member States were perceived, by the international financial market associations, as legal barriers to the efficient use of financial collateral arrangements, and describes the role of international financial market associations in advocating for a reform of the European law on financial collateral. The Chapter 5 of the paper examines how the market needs were addressed in the Financial Collateral Directive, and identifies the legal norms of the Financial Collateral Directive which have their origins in the financial market lex mercatoria. The conclusion is presented in Chapter 6 of the paper.

\section{THE BASICS OF FINANCIAL COLLATERAL ARRANGEMENTS}

A financial collateral arrangement may be defined as an arrangement that involves the delivery of financial assets as security or 'quasi-security' for financial obligations. ${ }^{7}$ The most important types of financial assets used as financial collateral in these arrangements are cash, securities, and credit claims. ${ }^{8}$ The

in Commercial Transactions, Edward Elgar Publishing, Cheltenham - Northampton, 2015, pp. 286-325.

7 See Murray, op. cit. (fn. 6), p. 286. Cf. Keijser, op. cit. (fn. 6), p. 3. For the term 'quasi-security', see infra, fn. 54.

8 See Benjamin, op. cit. (fn. 6), p. 445. 
financial assets used as financial collateral in the financial collateral arrangements are fungible intangible assets. ${ }^{9}$

Typically, in financial transactions which rely on financial collateral arrangements, the financial assets which serve as a financial collateral are transferred by the collateral provider to the collateral taker at the opening leg of the transaction, when the financial assets which serve as an agreed principal are transferred by the collateral taker to the collateral provider. The latter flow of the financial assets is the principal flow, whereas the former is the collateral flow. At the closing leg of the transaction, when the financial obligations of the collateral provider to the collateral taker have been performed, the equivalent assets to the assets used as financial collateral are transferred by the collateral taker to the collateral provider.

The financial collateral provided by the collateral provider to the collateral taker serves the purpose of securing financial obligations owed to the collateral taker. Moreover, for the collateral taker, it is a commercial imperative that he is allowed to deal freely with the financial collateral prior to the maturity of the obligation to transfer the equivalent assets to the collateral provider. The financial collateral provided to the collateral taker under a financial collateral arrangement is used for further trading in the financial markets. Thus, in financial transactions which rely on the financial collateral arrangements, the financial collateral serves two important functions: a recovery function and a tradability function..$^{10}$

The tradability function of the financial collateral in most jurisdictions cannot be achieved through the traditional security legal structures, such as pledge, which were historically developed mostly for tangible movable assets, since under these structures the collateral taker is regularly not allowed to dispose and to use the collateral during the ordinary lifetime of the transaction and may do so only if the collateral provider defaults on his obligations secured with the provided collateral. In order to grant the collateral taker with a general right of disposal of financial collateral, two methods of provision of financial collateral were developed in the financial markets: one that combines a creation of a security interest in favor of the collateral taker with the right of use of financial collateral ('security interest method'), and the other that transfers the full legal title to financial collateral to the collateral taker ('title transfer method'). ${ }^{11}$

\footnotetext{
$9 \quad$ See Johansson, op. cit. (fn. 5), pp. 2-3.

10 See Haentjens, M. and de Gioia-Carabellese, P.: European Banking and Financial Law, Routledge, London - New York, 2015, p. 214; Keijser, op. cit. (fn. 6), pp. 16-17.

11 See Keijser, op. cit. (fn. 6), pp. 15-16.
} 
Both methods of provision of financial collateral had been developed in the United States financial markets, where the most of the modern-day types of financial transactions that rely on financial collateral arrangements had originated. The title transfer method had been pioneered in the repo and securities lending markets, and in the early 1990s began to develop in the swaps segment of the over-the-counter ('OTC') derivatives markets, where earlier it was not common to take financial collateral to secure obligations under interest rate swaps and currency swaps. ${ }^{12}$ In the other segments of the OTC derivatives markets, financial collateral is often provided under the security interest approach. ${ }^{13}$

In the European financial markets, the most common types of collateralized transactions are repurchase transactions, sell/buy-back transactions, and securities lending transactions. In all of them, financial collateral is provided under the title transfer approach. The title transfer financial collateral arrangements had prevailed in the European financial market before the adoption of the Financial Collateral Directive, and they remained dominant after its transposition into the laws of EU Member States. ${ }^{14}$

\section{REPURCHASE TRANSACTIONS IN THE EUROPEAN REPO MARKET}

Of all the various types of financial transactions which rely on the financial collateral arrangements, a repurchase agreement is the only one to which the provisions of the Financial Collateral Directive explicitly refer. ${ }^{15}$ Repurchase agreements, also known as 'repos', belong to the family of securities financing transactions ('SFTs'), which are the subject matter of the recent SFTs Regulation. ${ }^{16}$

\footnotetext{
12 See Murray, op. cit. (fn. 6), p. 292. Cf.: Keijser, op. cit. (fn. 6), p. 14.

13 See Keijser, op. cit. (fn. 6), p. 16.

14 See Benjamin, op. cit. (fn. 6), p. 306.

15 See recitals 3, 13 and 14, and the Article 2 (1) (b) of the Financial Collateral Directive.

16 Regulation (EU) 2015/2365 of the European Parliament and of the Council of 25 November 2015 on transparency of securities financing transactions and of reuse and amending Regulation (EU) No 648/2012 (OJ L 337, 23/12/2015); hereinafter: SFTs Regulation. The objective of the SFTs Regulation is to increase the transparency of SFTs and of the reuse of the financial collateral under SFTs, by requiring, inter alia, SFTs to be reported to trade repositories. SFTs Regulation is a part of the ongoing European Commission efforts to tackle the risks related to 'shadow banking', a system of credit intermediation that involves entities and activities outside the regular banking system.
} 
Though it is commonly stated that the term 'repo' is an abbreviation of 'repurchase transaction' or of 'repurchase agreement', ${ }^{17}$ the term 'repo' more probably comes from a superseded expression 'repurchase option'. ${ }^{18}$ The term "repo" is used in the European repo market jargon as the generic term for two similar types of financial transactions: repurchase transaction, and sell/buy-back transaction. ${ }^{19}$ In the literature, the term 'repos' is sometimes used even in a broader sense, comprising repurchase transactions, sell/buy-back transactions, as well as the securities lending transactions, ${ }^{20}$ which have similar effects to the repurchase transactions. If not expressly stated otherwise, in the following subsections of the paper the term 'repo' is used only to refer to a 'repurchase agreement', which is also known in the European repo market jargon as a 'classic repo', 'US-style repo' or 'all-in repo'. ${ }^{21}$

The emergence, growth and current size of the European repo market are dealt with in the Subchapter 3.1, where the term 'repo market' refers to the market in repurchase transactions and sell/buy-back transactions. The standard market documentation used for repurchase agreements in the European repo market is described in the Subchapter 3.2. The legal structure of a repurchase transaction and its economic purpose are explained in the Subchapter 3.3. The Subchapter 3.4 deals with the specific features of repurchase transactions relating to margin maintenance methods, income payments, substitution of collateral, and the technique of close-out netting. The Subchapter 3.5 briefly explores the main differences between repurchase transactions and the two types of comparable transactions: sell/buy-back transactions and securities lending transactions.

\footnotetext{
17 See e. g. Benjamin, op. cit. (fn. 6), p. 308; Schindler, C., Hindelang, M.: Praxishandbuch Repos und Wertpapierdarlehen, Springer Gabler, Wiesbaden, 2016, p. 80.

18 See Gretton, op. cit. (fn. 6), p. 210.

19 See International Capital Market Association - European Repo and Collateral Council, A Guide to Best Practice in the European Repo Market, International Capital Market Association, Zurich, 2017, p. 106.

20 See $e$. g. Stadler, V. and Lanoo, K.: The EU Repo Markets: The Need for Full Integration, Centre for European Policy Studies, Brussels, 2000, p. 9.

21 See Choudhry, M.: The Repo Handbook, Butterworth-Heinemann, Oxford, 2010, pp. 115116; Comotto, R.: The European Repo Market, in Fabozzi, F. J. and Mann, S. V. (eds.), Securities Finance - Securities Lending and Repurchase Agreements, John Wiley \& Sons, Hoboken, 2005, p. 245; ICMA - ERCC, loc. cit. (fn. 19); Schindler and Hindelang, op. cit. (fn. 17), p. 80.
} 


\subsection{THE EUROPEAN REPO MARKET}

While in the United States the repo market has been in development since the $1920 \mathrm{~s},{ }^{22}$ the modern form of repurchase transaction and a cross-border repo market in Europe emerged in the late 1980s. Since the mid-1990s, the European repo market has largely grown and today it rivals the United States repo market in size and sophistication..$^{23}$ Amongst the several factors that contributed to the rapid growth of the European repo market, the development of the standard master agreement for repurchase agreements, the tightening of regulatory capital requirements and the shift out of unsecured lending, as well as the introduction of the euro in 1999, should be highlighted. ${ }^{24}$

The only authoritative source of data on the size and composition of the European repo market are the bi-annual surveys conducted by the European Repo and Collateral Council ('ERCC') of the International Capital Market Association ('ICMA'). ${ }^{25}$ According to the latest survey, the total value of European cross-border and domestic repos in December 2016 was 5,656 billion euro. ${ }^{26}$ In the total value of repos, sell/buy-back transactions are represented with around $15 \% .^{27}$

\subsection{THE STANDARD MASTER AGREEMENT FOR REPURCHASE TRANSACTIONS}

Parties to a repurchase agreement commonly enter into a master repurchase agreement which serves as a framework under which individual repurchase transactions between them can be concluded and documented. The terms and

\footnotetext{
22 On the origins and the development of the repo markets, see: Choudhry, op. cit. (fn. 21), pp. 7-8; Schindler and Hindelang, op. cit. (fn. 17), pp. 8-13.

23 For a discussion on the size, growth and composition of the European repo market, see: Comotto, op. cit. (fn. 21), pp. 241-253.

24 See ibid., p. 242.

25 International Capital Market Association ('ICMA') is the current name of the earlier International Securities Market Association ('ISMA'), which in 2005 merged with the International Primary Market Association. Originally, ISMA was founded in Zurich in 1969 as the Association of International Bond Dealers ('AIBD'), but changed its name to ISMA in 1992. European Repo Council ('ERC') of the ISMA was established in 1999 to represent the cross-border repo market in Europe, but changed its name to European Repo and Collateral Council ('ERCC') in 2015.

26 See International Capital Market Association, European Repo Market Survey - Number 32 - Conducted December 2016, International Capital Market Association, Zurich, 2017, p. 4.

27 See ibid., p. 18.
} 
conditions contained in the master repurchase agreement apply to all individual repurchase transactions concluded between the parties. The individual repurchase transactions are typically concluded in the interdealer electronic trading on automatic trading systems, and over the telephone by the voice-brokers. The specific terms of an individual repurchase transaction are documented in a written confirmation of the transaction, which is delivered by one of the parties to the other, promptly after the transaction is concluded.

The standard master agreement most widely used in the European cross-border repo market to document repurchase transactions is the Global Master Repurchase Agreement ('GMRA'), prepared and published by the ICMA and the Securities Industry and Financial Markets Association ('SIFMA'). ${ }^{28}$ The first version of the GMRA, published in 1992, was based on the standard master agreement developed for the United States repo market by the PSA. The revised version of the GMRA was published in 1995. The publication of this improved version of the GMRA is considered to be one of the key triggers for the rapid growth of the European cross-border repo market that started in the mid-1990s. ${ }^{29}$ The next version of the GMRA was published in 2000 ('GMRA 2000'), while the current version of the GMRA is the one published in 2011 ('GMRA 2011'). ${ }^{30}$

In addition to the GMRA, the standard annexes to the GMRA are also prepared and published by the ICMA and the SIFMA. While the GMRA sets out the general provisions that apply to all individual transactions concluded under the GMRA, the supplemental terms and conditions are provided in Annex I to the GMRA. This Annex enables the parties to elect supplemental terms and conditions which will apply together with the GMRA to all individual repurchase transactions concluded between them. The Annex II to the GMRA contains a standard form of confirmation that is used to document the specific terms of an individual transaction, but the parties to the GMRA may also agree to use any other form of the confirmation. ${ }^{31}$ Also, several standard annexes to the GMRA 2011 are published, which deal with the special types of repos and legal issues specific to certain countries. ${ }^{32}$

28 SIFMA is a United States based financial market association which was created in 2007 through the merger of The Bond Market Association ('TBMA') and the Securities Industry Association ('SIA'). TMBA was formed in 1976 as the Public Securities Association ('PSA'), but changed its name to TMBA in 1997. SIA was created in 1971 through the merger of the Investment Bankers Association of America ('IBA'), which was founded in 1912, and the Association of American Stock Exchange Firms ('ASEF'), which was formed in 1913.

29 See Comotto, op. cit. (fn. 21), p. 242.

30 References to the GMRA in this paper are made to the current version, GMRA 2011.

31 See Paragraph 3 (b) of the GMRA 2011.

32 These are Buy/Sell Back Annex to the GMRA 2011, Bills Annex to the GMRA 2011, Agency Annex to the GMRA 2011, Equities Annex to the GMRA 2011, Gilts Annex to the 
Though there are also a number of standard market agreements in use in the domestic repo markets in the European countries, ${ }^{33}$ besides being the market standard for the European cross-border repo market, GMRA is also relevant for trade in several of the national repo markets. While in some national repo markets the GMRA is also the market standard master agreement, ${ }^{34}$ in developing national repo markets the GMRA is heavily used as a model for standard master repurchase agreements prepared by the national financial associations. ${ }^{35}$

\subsection{THE LEGAL STRUCTURE AND THE ECONOMIC PURPOSE OF A REPURCHASE TRANSACTION}

A repurchase transaction or a classic repo is a transaction governed by an agreement that one party ('the seller') will sell securities to another party ('the buyer') at a certain date ('the purchase date') at an agreed price ('the purchase price'), with a simultaneous commitment by the seller to buy equivalent securities from buyer at a future date or on demand ('the repurchase date') at a different price ('the repurchase price'). ${ }^{36}$ The transaction is referred to as a 'repo'

GMRA 2011, Russian Annex to the GMRA 2011, Canadian Annex to the GRMA 2011, and the Italian Annex to the GMRA 2011.

33 E. g. Deutscher Rahmenvertrag für Wertpapierpensionsgeschäfte (Repos), in the German repo market; Convention-Cadre FBF Relative aux Opérations de Pension Livrée, in the French repo market. Also, the harmonised multi-product master agreement that can be used in the domestic markets in the Eurozone was developed in 2001 by the European Bank Federation, in cooperation with the European Savings Bank Group and the European Association of Cooperative Banks: the Master Agreement for Financial Transactions, commonly known as the European Master Agreement ('EMA'). The annexes to the EMA, relating to repurchase agreements, are: Product Annex for Repurchase Transactions and Margin Maintenance Annex for Repurchase Transactions and Securities Loans. On the EMA, see Comotto, op. cit. (fn. 21), p. 251; Keijser, op. cit. (fn. 6), pp. 42-45.

34 GMRA is the market standard master agreement, e. g., in the United Kingdom repo market. See: Benjamin, op. cit. (fn. 6), p. 307; Lomnicka, E.: Financing Devices Involving the Transfer or Retention of Title, in Beale, H., Bridge, M., Gullifer, L. and Lomnicka, E.: The Law of Security and Title-Based Financing, Oxford University Press, Oxford, 2012, p. 271.

35 E. g., in the Croatian repo market, the Standard Master Repo Agreement (Okvirni repo ugovor; 'ORU') is in use for domestic repo transactions. ORU is published by the two national financial market associations (ACI Croatia, and the Croatian Banking Association). The current version of ORU, published in 2014, is almost a letter-by-letter translation of the GMRA 2011 into Croatian language.

36 Cf. Benjamin, op. cit. (fn. 6), p. 308; Choudhry, op. cit. (fn. 21), pp. 115-116; Fabozzi, F. J. and Mann, S. V.: Repurchase and Reverse Repurchase Agreements, in Fabozzi and Mann, op. cit. (fn. 21), p. 222; Haentjens and de Gioia-Carabellese, op. cit. (fn. 10), p. 211; Keijser, op. cit. (fn. 6), p. 11; Lomnicka, op. cit. (fn. 34), p. 270; Schindler and Hindelang, op. cit. (fn. 17), p. 80. Also, see definitions of repurchase transaction in the paragraph 1 (a) of the GMRA 2011 
when looked at from the point of view of the seller, whereas from the buyer's point of view the same transaction is commonly referred to as a 'reverse repo'.

For the understanding of the legal structure and the economic purpose of a repurchase transaction, it is important to differentiate the distinctive flows of cash and securities that take place at the purchase date (also known as the 'settlement date ${ }^{37}$ ) and at the repurchase date (also known as the 'termination date' $\left.^{38}\right)$.

At the purchase date, the buyer transfers cash to the seller, while the seller transfers securities to the buyer. The transfer of securities and the payment of the purchase price against the transfer of the securities are to be made simultaneously. ${ }^{39}$ The transfer of the securities is an outright transfer of a full legal title to securities from the seller to the buyer. ${ }^{40}$

At the repurchase date, ${ }^{41}$ the buyer transfers securities to the seller, while the seller simultaneously pays the repurchase price to the buyer. ${ }^{42}$ A full legal title to securities is transferred from the buyer to the seller. ${ }^{43}$ The buyer is not obliged to transfer the same securities which were previously transferred to him by the seller. The obligation of the buyer is to transfer the 'equivalent' securities,

and in the Article 3 (9) of the SFTs Regulation. A definition of a repurchase transaction is not provided in the Financial Collateral Directive.

37 In the GMRA 2011, the term 'purchase date' is used and it is defined as 'the date on which Purchased Securities are to be sold by Seller to Buyer' (see paragraph $2(\mathrm{~mm})$ of the GMRA 2011). In the repo market jargon, different terms are used in place of purchase date, such as 'settlement date', 'start date', 'value date', and 'on-side date'. The purchase date is also referred to as the 'first leg' or the 'opening leg' of a repurchase transaction. The purchase date or the settlement date is to be differentiated from the 'transaction date' or 'trade date', which is the day on which a repurchase transaction is entered into by the seller and the buyer. For a detailed description of the market practices and terminology used regarding fixing the purchase date, see: ICMA - ERCC, op. cit. (fn. 19), pp. 10-15.

38 In the GMRA 2011, the term 'repurchase date' is defined as 'the date on which Buyer is to sell Equivalent Securities to Seller ' (see Paragraph 2 (qq) of the GMRA 2011). In the repo market practice, the repurchase date is also commonly referred to as 'termination date', 'offside date', the 'second leg', and the 'closing leg' of a repurchase transaction.

39 See Paragraph 6 (c) of the GMRA 2011.

40 This is made clear in the Paragraph 6 (e) and (f) of the GMRA 2011.

${ }^{41}$ In fixed-term repos, the repurchase date is a specific date agreed between the parties on the transaction date. If the repurchase date is not fixed on the transaction date, but can be called at any time by either the buyer or the seller, subject to a minimum period of notice to the other party, such repo is known as an 'open repo'. In the GMRA 2011, an open repo is referred to as an 'on demand transaction' (see Paragraph 3 (e) of the GMRA 2011).

42 See Paragraph 6 (c) of the GMRA 2011.

43 See Paragraph 6 (e) of the GMRA 2011. 
i.e. the securities that are of the same issuer, are part of the same issue and are of an identical type, nominal value, description and amount as the securities which were purchased at the purchase date. ${ }^{44}$ This contractual obligation of the buyer is owed to seller personally, not proprietary. ${ }^{45}$

Although a repurchase transaction is legally structured as a combination of a spot sale and a forward purchase of securities, most repurchase transactions are cash-driven transactions which are motivated by the need to borrow and lend cash. Cash-driven repurchase transactions are in their economic substance essentially secured loans of cash. ${ }^{46}$

At the purchase date, the seller is borrowing the cash and providing securities as collateral. The purchase price is paid by the buyer as a means to advance the cash, while the securities transferred to the buyer serve as financial collateral for the repayment of the advanced cash. Therefore, the cash flow is the principal flow, whereas the securities flow is the collateral flow. ${ }^{47}$ At the repurchase date, the buyer transfers equivalent securities to the seller against a repurchase price which is typically higher than the purchase price paid by the buyer at the purchase date. The repurchase price equals the purchase price plus a price differential. The price differential is calculated on the basis of the agreed 'pricing rate', ${ }^{48}$ also commonly known in the market as the 'repo rate'. Repo rate is essentially an interest rate, while the price differential is in its economic substance an amount of interest. ${ }^{49}$

European repo market typically uses fixed-income securities, such as government bonds, as financial collateral, but a part of the market also deals with equity securities, such as ordinary shares. If the buyer in a repurchase transaction is willing to accept any securities of a certain type as collateral, such securities are referred to as 'general collaterals', or 'GCs' ${ }^{50} \mathrm{GC}$ repos are typically cash-driven transactions. Repurchase transactions can also be securities-driven transactions, from the buyer's point of view, if specific securities

\footnotetext{
44 See Paragraph 2 (v) of the GMRA 2011.

45 Cf. Benjamin, op. cit. (fn. 6), p. 317; Choudhry, op. cit. (fn. 21), p. 346.

46 Cf. Benjamin, op. cit. (fn. 6), p. 308; Choudhry, op. cit. (fn. 21), p. 5; Fabozzi and Mann, op. cit. (fn. 36), p. 222; Haentjens and de Gioia-Carabellese, op. cit. (fn. 10), p. 211.

$47 C f$. Benjamin, op. cit. (fn. 6), p. 308; Haentjens and de Gioia-Carabellese, op. cit. (fn. 10), p. 211; Keijser, op. cit. (fn. 6), p. 11.

48 In the Paragraph 2 (11) of the GMRA 2011, 'pricing rate' is defined as 'with respect to any Transaction, the per annum percentage rate for calculation of the Price Differential agreed to by Buyer and Seller in relation to that Transaction'.

49 Cf. Benjamin, op. cit. (fn. 6), p. 308; Haentjens and de Gioia-Carabellese, op. cit. (fn. 10), p. 217; Keijser, op. cit. (fn. 6), p. 27.

$50 \quad$ See Choudhry, op. cit. (fn. 21), p. 147.
} 
are in high demand in the market. Such securities are known as 'specials' and are sold in the market at a repo rate which is lower than the repo rate at which general collaterals are sold. ${ }^{51}$

The term 'collateral' is used in the repo market jargon to refer to the securities sold at the purchase date, ${ }^{52}$ yet these are not collateral in the traditional legal sense of the term. In a repurchase transaction, the full legal title to the securities delivered as 'collateral' is transferred outright from the seller to the buyer and the buyer may deal with the securities as he deems fit, subject only to his contractual obligation to deliver the equivalent securities to the seller at the repurchase date. The term 'collateral' is not used in the GMRA 2011, which also makes it clear that, notwithstanding the expressions used in the GMRA 2011, such as 'repurchase date' and 'repurchase price', which are used in the GMRA 2011 'to reflect terminology used in the market', 'all right, title and interest in and to' securities transferred from the seller to the buyer 'shall pass to the transferee'. ${ }^{53}$ A repurchase transaction relies on a title transfer financial collateral arrangement, which is referred to in the literature as 'quasi-security', since it has the comparable economic effect to security, but does not involve the creation of a de jure security interest. ${ }^{54}$

\subsection{THE SPECIFIC FEATURES OF A REPURCHASE TRANSACTION}

\subsubsection{MARGIN AND MARGIN MAINTENANCE}

In a repurchase transaction the agreed purchase price of the securities, which are to be transferred by the seller to the buyer at the purchase date, is typically set lower than the market value of the securities at the transaction date, resulting in an over-collateralization. The purchase price of the securities is calculated in one of two ways: (a) by deducting a percentage discount from the market value of securities, which is known as 'haircut' or 'margin percentage', or (b) by adding a percentage premium to the market value of securities, which is known as 'initial margin' or 'margin ratio'. ${ }^{55}$ Over-collateralization is used

\footnotetext{
51 See ibid., p. 148.

52 See ICMA - ERCC, op. cit. (fn. 19), p. 89; Keijser, op. cit. (fn. 6), pp. 19-20.

53 See Paragraph 6 (f) of the GMRA 2011.

54 Cf. Benjamin, op. cit. (fn. 6), p. 307; Murray, op. cit. (fn. 6), p. 288.

55 For a detailed explanation of the differences between haircuts and initial margins, and of their use in the repo market, see: Comotto, R.: Haircuts and Initial Margins in the Repo Market, ICMA European Repo Council, Zurich, 2012. In the GMRA 2011, a haircut is referred to as a 'margin percentage' (see: Paragraph 2 (aa) of the GMRA 2011), whereas an initial margin is called a 'margin ratio' (see: Paragraph 2 (bb) of the GMRA 2011).
} 
to protect the buyer against downward price fluctuations of the provided securities, which may lead to difficulties for the buyer when selling these securities in the market. ${ }^{56}$ The excess amount of securities over the purchase price is known as 'margin', and it is to be maintained during the entire course of the repurchase transaction.

In the course of a repurchase transaction, the market value of equivalent securities, which are to be transferred by the buyer to the seller at the repurchase date, may change, leading to one of the parties being exposed to the other as a result of price fluctuations. In order to eliminate this risk, repurchase agreements employ procedure known as a 'margin maintenance', the purpose of which is to maintain the originally set balance between the market value of the securities and the agreed purchase price. This balance is maintained by a practice known as 'marking to market', which means recording the positions of the parties at the market values and adjusting the positions when a change in market values occurs. Marking collateral to market is used to determine the 'transaction exposure' of the one party to the other, with respect to an individual repurchase transaction concluded between the parties. ${ }^{57}$ The transaction exposures in all of individual repurchase transactions concluded under the master repurchase agreement are taken into account in order to determine the "net exposure' of the one party to the other. A party has a net exposure in respect of the other party if the aggregate of all of the party's transaction exposures exceeds the aggregate of all of the other party's transaction exposures. ${ }^{58}$

If at any time either party has a net exposure in respect of the other party, it may require by notice (known as a 'margin call'), the other party to deliver additional securities (known as 'margin securities') or cash (known as 'cash margin') in order to restore the agreed balance between the price and the value of securities. ${ }^{59}$ This method of margin maintenance is known as a 'margin transfer'. ${ }^{60}$ The party who had called for a margin transfer and had received a margin (cash margin or margin securities) from the other party has an obligation at the end of the transaction to retransfer to the other party the equivalent margin (cash margin together with interest or equivalent margin securities).

\footnotetext{
56 Cf. Comotto, op. cit. (fn. 55), p. 5; Haentjens and de Gioia-Carabellese, op. cit. (fn. 10), p. 217.

57 For the formula used to determine the 'transaction exposure', see: Paragraph 2 (xx) of the GMRA 2011.

58 For a full definition of the 'net exposure', see: Paragraph 4 (c) of the GMRA 2011.

59 See definitions of 'cash margin' and 'margin securities' in the Paragraph 2 (h) and (cc) of the GMRA 2011.

60 For margin transfers under the GMRA 2011, see: Paragraph 4 (a) - (i) of the GMRA 2011.
} 
Instead of margin transfers, two other methods of margin maintenance may be used: repricing, and adjustment. ${ }^{61}$ These methods are used in cases of extreme changes in market values, for which cases margin transfers are not considered to be the most appropriate stabilization instrument. ${ }^{62}$

\subsubsection{INCOME PAYMENTS AND THE MANUFACTURED DIVIDEND}

Since the full legal title to the securities used as collateral in a repurchase transaction is transferred at the purchase date to the buyer, the buyer is entitled to interest, dividends or any other earnings on the collateral. However, the Paragraph 5 of the GMRA 2011 provides for a contractual obligation of the buyer to pay to the seller an amount equal to such income payment, unless otherwise agreed between the parties. This amount is known as a 'manufactured dividend' and is given to the seller, who retains economic benefits of the collateral although not the legal title to collateral, as a compensation for the implied loss of income during the course of a repurchase transaction. ${ }^{63}$

\subsubsection{SUBSTITUTION OF COLLATERAL}

If a seller wishes to withdraw collateral for any reason, such as the need for the use of collateral in another transaction or for exercising the voting rights attached to the collateral, he may do so only if a right to substitute the collateral is given to him under a repurchase agreement. Under the provisions of Paragraph 8 of the GMRA 2011, the seller is not generally entitled to a right to substitute the previously sold securities. He may request the substitution from the buyer but the substitution will be executed only if the buyer agrees to the requested substitution. If the buyer agrees to a substitution, the seller is obliged to transfer alternative collateral to the buyer. In exchange for the buyer's permission to substitute the collateral at any time between the purchase date and the repurchase date, the seller will usually agree to pay a higher repo rate. ${ }^{64}$

\footnotetext{
${ }^{61}$ In the case of repricing, the obligations of the parties under the original transaction are accelerated and revalorised (see: Paragraph 4 (k) of the GMRA 2011). In the case of adjustment, the original transaction is terminated and replaced with a new transaction (see: Paragraph 4 (l) of the GMRA 2011).

62 See Haentjens and de Gioia-Carabellese, op. cit. (fn. 10), p. 218.

63 See Benjamin, op. cit. (fn. 6), p. 320; Choudhry, op. cit. (fn. 21), p. 312.

${ }^{64}$ See ICMA - ERCC, op. cit. (fn. 19), pp. 20-21.
} 


\subsubsection{THE TECHNIQUE OF CLOSE-OUT NETTING}

A repurchase transaction is ordinarily terminated on the repurchase date when the buyer transfers equivalent securities to the seller against the payment of the repurchase price. An early termination of a repurchase transaction might occur in the event of a default of one of the parties. The Paragraph 10 of the GMRA 2011 contains the provisions on events which are considered to be 'events of default'. ${ }^{65}$ Depending on the circumstances, an event of default may lead to the termination of a single repurchase transaction, or to the 'early termination' of all of the individual repurchase transactions concluded between the seller and the buyer.

The early termination of all outstanding transactions usually takes place after a notice given to the defaulting party in which the non-defaulting party specifies the relevant event of default and designates an 'early termination date' in respect of all outstanding transactions, but the parties may also agree that an 'automatic early termination' will occur in the event of default, without the need for a special notice. ${ }^{66}$ Designation of an early termination date, or an occurrence of an automatic early termination, leads to a close-out netting of all of the outstanding obligations of the parties under a master repurchase agreement.

The close-out netting consists of the following: (a) the acceleration of the time for performance of all obligations of the parties to the early termination date; (b) valuation of all obligations of the parties at the market values on the early termination date; (c) the conversion of non-cash obligations into monetary obligations; (d) the conversion of all monetary obligations into a single currency; (e) the aggregation of all of the monetary obligations of the parties to the two net obligations of the parties; (f) set-off of the net obligations of the parties, resulting in a single monetary obligation by one party to the other. ${ }^{67}$

\footnotetext{
${ }^{65}$ E. g. failure of buyer to pay the purchase price at the purchase date, failure of seller to pay the repurchase price at the repurchase date, occurrence of an 'act of insolvency' with respect to seller or the buyer. For a definition of an 'act of insolvency', see: Paragraph 2 (a) of the GMRA 2011.

66 See Paragraph 10 (b) of the GMRA 2011.

67 The described technique of the close-out netting is not unique to the master repurchase agreements, as close-out netting provisions are included in the standard market agreements for various financial transactions, such as securities lending transactions, forwards, and options. On close-out netting, see: Benjamin, op. cit. (fn. 6), pp. 267-273.
} 


\subsection{THE MAIN DIFFERENCES BETWEEN REPURCHASE TRANSACTIONS AND COMPARABLE TRANSACTIONS}

\subsubsection{THE MAIN DIFFERENCES BETWEEN A REPURCHASE TRANSACTION AND A SELL/BUY-BACK TRANSACTION}

A sell/buy-back transaction has the same transaction structure and economic purpose as a repurchase transaction. The transaction is referred to as a 'sell/ buy-back' when looked at from the point of view of the seller, whereas from the buyer's point of view the same transaction is commonly referred to as a 'buy/ sell-back'. Unlike repurchase transaction in which the spot sale and the forward purchase of securities are a part of a single agreement, in a sell/buy-back transaction parties enter simultaneously in a spot sale and a forward purchase as two separate agreements. The seller simultaneously agrees to sell securities to the buyer at a spot price and to buy equivalent securities from the buyer at a forward price which is typically higher than a spot price. The 'repo rate' is not explicit as in a repurchase agreement, but is however implied in the agreed forward price. ${ }^{68}$

Except for the confirmations for the spot sale and the forward purchase, the sell/buy-back transactions were traditionally undocumented transactions, but parties wishing to document their sell/buy-back transactions may do so by supplementing their master repurchase agreement with a separate annex. The standard Buy/Sell Back Annex to the GMRA is published and widely used for this purpose. In an undocumented sell/buy-back, which is not subject to a master agreement, the seller has no right to an amount equal to the income payment on collateral, and there is no provision for techniques such as marking to market, margin maintenance, substitution of a collateral, and close-out netting. If a sell/buy-back transaction is documented under the Buy/Sell Back Annex to the GMRA 2011, the margin maintenance methods provided in the GMRA 2011 are to be applied, as well as the provisions on the substitution of collateral and close-out netting. A documented sell/buy-back is not terminable on demand. ${ }^{69}$ The provisions of GRMA 2011 relating to income payments are not applied to documented sell/buy-back transactions. ${ }^{70}$ An amount equal to the income payment on collateral is to be paid to the seller, but this is done through incorporation into the forward price, so the seller will receive it only at the termination of the sell/buy-back transaction. ${ }^{71}$ Despite the availability

\footnotetext{
68 For sell/buy-back transactions, see, e.g.: Benjamin, op. cit. (fn. 6), p. 309; Choudhry, op. cit. (fn. 21), pp. 121-127; Fabozzi and Mann, op. cit. (fn. 36), p. 237.

69 See Paragraph 3 (d) of the Buy/Sell Back Annex to the GMRA 2011.

70 See Paragraph 5 of the Buy/Sell Back Annex to the GMRA 2011.

71 See Choudhry, op. cit. (fn. 21), p. 123.
} 
of the Buy/Sell-Back Annex to the GMRA, a large market in undocumented sell/buy-back transactions still exists in Europe but is mainly concentrated in domestic repo markets, whereas in the European cross-border repo market documented sell/buy-backs are more common. ${ }^{72}$

\subsubsection{THE MAIN DIFFERENCES BETWEEN A REPURCHASE TRANSACTION AND A SECURITIES LENDING TRANSACTION}

A securities lending transaction is a transaction governed by an agreement that one party ('the lender') will transfer securities to another party ('the borrower') at a certain date against the transfer of collateral (cash or other securities) by borrower to lender, with a simultaneous commitment by the borrower to transfer to the lender equivalent securities at a future date or on demand against the transfer of assets equivalent to collateral to borrower by lender. ${ }^{73}$ The securities lending market in Europe is represented by the International Securities Lending Association ('ISLA'). Securities lending transactions are typically documented and governed by the Global Master Securities Lending Agreement ('GMSLA') which was updated by ISLA in 2012.

The securities lending agreement is legally structured as a combination of two loan transactions under a single agreement. Although securities lending market jargon uses the expressions 'borrower' and 'lender', in a secured lending transaction the full legal title to the 'borrowed' securities is transferred outright from the 'lender' to the 'borrower' ${ }^{74}$ Due to this similarity, a repurchase transaction and a securities lending transaction can be used as substitutes for each other. From the perspective of the borrower, securities lending is a specific securities-driven transaction in which the borrower is motivated by the need to borrow special securities. This is a key difference from the cash-driven repurchase transactions which are mostly for general collateral. However, there exists an overlap between securities lending and the 'specials' segment of the repo market. The securities used in securities lending transactions are typically either equity securities or government bonds. In the recent years, the European securities lending market has seen the most growth in the segment which deals with the government bonds. ${ }^{75}$

\footnotetext{
72 See Comotto, op. cit. (fn. 21), p. 251.

73 Cf. Benjamin, op. cit. (fn. 6), p. 309; Choudhry, op. cit. (fn. 21), p. 127; Haentjens and de Gioia-Carabellese, op. cit. (fn. 10), p. 212; Keijser, op. cit. (fn. 6), p. 12.

74 See Paragraph 2 (3) of the GMSLA.

75 See International Securities Lending Association, ISLA Securities Lending Market Report - 6th Edition - December 2016, International Securities Lending Association, London, 2016, p. 6.
} 


\section{THE BACKGROUND TO THE FINANCIAL COLLATERAL DIRECTIVE: ADVOCATING THE LEGAL CHANGE}

With the rise of the European cross-border financial market, the market participants became aware of the legal obstacles to the efficient use of financial collateral in cross-border transactions, created by the non-harmonized national laws of the EU Member States. Both of the methods for the provision of financial collateral that were developed in the market practice were faced with legal restrictions in the different domestic laws.

The legal risks and uncertainties relating to the use of financial collateral, as perceived by the financial market participants, are discussed in the Subchapter 4.1. As repurchase transactions are used in this paper to illustrate the mechanics of a financial collateral arrangement, the discussion will mainly concern the title transfer method for provision of financial collateral, which is utilized in such transactions. The involvement of the international financial market associations in the legislative process leading to the adoption of the Financial Collateral Directive is examined in the Subchapter 4.2.

\subsection{IDENTIFYING THE LEGAL BARRIERS TO THE EFFICIENT USE OF FINANCIAL COLLATERAL}

The legal risk was singled out in the 1990s by international financial market associations as a crucial issue for establishing effective and efficient collateral arrangements. A key role in identifying the legal barriers to the efficient use of financial collateral in cross-border financial transactions was played by the International Swaps and Derivatives Association ('ISDA'). ${ }^{76}$ ISDA has published several papers and reports which highlighted the main legal issues relating to financial collateral arrangements, which have arisen in the jurisdictions of the then fifteen EU Member States. ${ }^{77}$ In these papers and reports, the financial collateral arrangements which rely on a security interest method for the provision of financial collateral were referred to as 'pledge collateral arrangements', whereas the financial collateral arrangements which rely on a title transfer

\footnotetext{
76 International Swaps and Derivatives Association ('ISDA') was established in 1985 and today is the leading global trade association representing the derivatives industry.

77 See especially: Credit Risk and Regulatory Capital, International Swaps and Derivatives Association, 1998 ('ISDA Paper'); Guidelines for Collateral Practitioners, International Swaps and Derivatives Association, 1998 ('ISDA Guidelines'); ISDA 1999 Collateral Review, International Swaps and Derivatives Association, 1999 ('ISDA Collateral Review'); Collateral Arrangements in the European Financial Markets - The Need for National Law Reform, International Swaps and Derivatives Association, London, 2000 ('ISDA Report').
} 
method were referred to as 'title transfer collateral arrangements'. Some of the legal impediments identified by ISDA concerned the security interest method, some the title transfer method, while some were associated to the both of the methods for the provision of financial collateral.

In relation to the security interest method for the provision of financial collateral, one of the main concerns was the invalidity of 'pledge collateral arrangements' that were not in conformity with the strict national rules for creating, perfecting, maintaining and enforcing collateral arrangements that employ the security interest method, which rules were perceived as cumbersome and impractical. ${ }^{78}$ An additional legal impediment relating to "pledge collateral arrangements' were the legal restrictions on the use of financial collateral by the collateral taker in the course of a collateralized transaction. In most of the European jurisdictions, it was not possible for a collateral taker to deal freely with the financial collateral provided under the arrangement that employs a security interest method, as the national laws were treating such arrangements in the same manner as traditional pledges. ${ }^{79}$

78 E. g., the ISDA Report stated that: 'Several European jurisdictions, namely England, France, Greece, Ireland, Netherlands, Portugal and Spain, have potentially burdensome formal requirements for the creation of a pledge or other security interest, particularly in relation to securities. These requirements are generally thought to be so burdensome as to lead financial market participants to prefer title transfer collateral, as in England, France and Ireland.' (ISDA Report, supra in note 77, p. 6.). Also, it was observed that: 'All European jurisdictions appear to require, at a minimum, notice to a third party custodian holding pledged assets that the assets are subject to a security interest. These notice requirements vary in their degree of formality and, therefore, of inconvenience. Several, however, go beyond this in certain circumstances and require either an acknowledgement by the custodian of the security interest or an annotation by the custodian on the account of the existence of the security interest, namely, Denmark, Finland, France, Italy, Luxembourg, Netherlands, Portugal and Spain. The Portuguese requirement is particularly burdensome in that each transfer of collateral appears to require a separate notification and annotation in the records of the custodian. Needless to say, acknowledgement and/or annotation requirements can be particularly burdensome in practice given the volume and frequency of securities flows involved.' (Ibid.)

79 E. g., the ISDA Report stated that: 'In all European jurisdictions other than England, Greece and Ireland, it is not possible for a pledgee to use the pledged assets as though it were the absolute owner of those assets. In Italy, although it is not possible under a traditional pledge for a pledgee to use the pledged assets, it may do so under an irregular pledge. There is some academic discussion in Germany whether there is a similar possibility of creating an irregular pledge in this sense. The position in Germany is, however, subject to debate. In either case, an irregular pledge does not appear to be a security interest in the normal sense (that is, a form of proprietary interest by way of security), but seems instead to be in substance a form of transfer of title, albeit for a limited purpose. In England and Ireland, use of the pledged (charged) assets by the pledgee (chargee) may be permitted by the underlying contract, but it remains unclear whether this is consistent with the nature of a security interest and therefore what the effect of such use is.' (Ibid., p. 7.). 
In relation to the title transfer method for the provision of financial collateral, legal uncertainty existed regarding the enforceability of a title transfer collateral arrangement, since in several jurisdictions there was a risk of re-characterization of such financial collateral arrangements as arrangements creating a security interest in the collateral. This was of special concern to the financial market participants, since the title transfer method had been developed by the market to avoid difficulties with the rules for perfection of a 'pledge collateral' and in response to restrictions on the use of pledged collateral by the collateral taker, so the purpose of the title transfer collateral arrangement would be defeated if it was to be re-characterized as a pledge collateral arrangement. ${ }^{80}$

In addition to the risk of re-characterization, the provisions of the national insolvency laws which prohibit or restrict the insolvency set-off were identified as a legal impediment to the efficient enforcement of the title transfer collateral arrangements. If the close-out netting technique employed in the standard market documentation was not to be legally recognized, in the event of the insolvency of the collateral provider, the collateral taker would be treated as an unsecured creditor and would not be released from his obligation to deliver the equivalent securities. ${ }^{81}$

'Marking to market' practices also appeared to be vulnerable to the rules of the insolvency laws in several jurisdictions, especially to the preference rules which enable the liquidator to avoid transactions entered into during the 'suspect period' leading to the insolvency order, and to the 'zero-hour' rules which give a declaration of insolvency the retroactive effect from the beginning of the day on which the insolvency is declared. Margin transfers or deliveries of a 'top-up collateral' could be invalidated under those rules by the liquidator, resulting in the obligation of the party to return the 'top-up collateral' to the insolvent estate without any protection against its exposure to the insolvent other party. ${ }^{82}$

${ }_{80}$ See ibid., p. 7; Yeowart and Parsons, op. cit. (fn. 6), p. 19. Cf.: Benjamin, op. cit. (fn. 6), p. 323; Choudhry, op. cit. (fn. 21), p. 346; Keijser, op. cit. (fn. 6), p. 71.

${ }_{81}$ See ISDA Report, op. cit. (fn. 77), p. 8. E. g., the ISDA Report stated that: 'Spain also prohibits insolvency set-off, so a title transfer based arrangement would not work even if it were not recharacterised.' (Ibid.)

82 See ibid., pp. 9-10. The ISDA Report stated that: 'There is a material risk that top-up collateral deliveries may be vulnerable as a preference during the relevant suspect period in each of Denmark, France, Greece, Italy and Spain.' (Ibid., p.10). 


\subsection{THE IMPETUS FOR, AND SUBSEQUENT SUCCESS OF, THE REFORM OF LAW ON FINANCIAL COLLATERAL}

The ISDA played not only a key role in identifying the legal barriers to the efficient use of financial collateral in cross-border financial transactions but was also strongly involved in the legislative process leading to the adoption of the Financial Collateral Directive.

Among other influential expert groups, ISDA was represented in the Giovannini Group, a group of financial market experts summoned by the European Commission in 1996 to give advice on financial market integration. ${ }^{83}$ After identifying in 1998 the legal risk as crucial in establishing effective and efficient collateral arrangements ${ }^{84}$ in 1999 ISDA urged the Internal Market Directorate General of the European Commission to take action to reform and harmonize national laws relating to collateral. ${ }^{85}$ In March 1999, the ISDA's paper "Collateral Arrangements in the European Financial Markets: the Need for Law Reform" was presented to the Giovannini Group. ${ }^{86}$

Subsequently, a legislative action on financial collateral was adopted by the European Commission as one of the core objectives of the Commission's 'Financial Services Action Plan' in May 1999, ${ }^{87}$ and a Forum Group on Collateral, consisted of financial market experts, was formed by the Commission in September 1999 to advise the Commission on problems associated with the cross-border use of collateral.

\footnotetext{
83 See Gabor, D., Ban, C.: Banking on Bonds: The New Links Between States and Markets, Journal of Common Market Studies, 54 (3) 2016, p. 623.

84 See $e$. g. ISDA Paper, op. cit. (fn. 77), pp. 30-32.

85 See ISDA Report, op. cit. (fn. 77), p. 13.

86 This paper, prepared by ISDA in February 1999, seems to be an earlier version of the ISDA Report which was issued in March 2000.

87 Communication from the Commission - Implementing the Framework for Financial Markets: Action Plan, COM (1999) 232 final, 11/5/1999 ('Financial Services Action Plan'). The Financial Services Action Plan stated: 'Work on the implementation of the Settlement and Finality Directive shows the importance of common rules for collateral pledged to payment and securities systems. Priority should be given to further progress in the field of collateral beyond this field. The mutual acceptance and enforceability of crossborder collateral is indispensable for the stability of the EU financial system and for a cost-effective and integrated securities settlement structure. At present, these conditions are not fulfilled: there is a higher risk of invalidation of crossborder collateral arrangements and uncertainty as regards enforceability should the collateral provider become insolvent. If such difficulties are not resolved, cross-border securities transactions will be subject to higher costs and risks. In close cooperation with the financial services sector and national authorities, the Commission will begin work on proposals for legislative action on collateral.' (See ibid., p.6).
} 
In October 1999, the Giovannini Group submitted to the European Commission the report "The EU Repo Markets: Opportunities for Change", which highlighted the areas in need of reform and called for an integration of a European repo market.

In order to assist the European Commission, ISDA formed a Collateral Law Reform Group in 2000. In March 2000, the Collateral Law Reform Group issued the ISDA Report which identified the legal impediments to the efficient use of collatera ${ }^{88}$ and proposed a set of principles that an effective and efficient modern legal regime for collateral arrangements should embody.

Several financial market experts were members of both the ISDA Collateral Law Reform Group and of the EC Forum Group on Collateral, ${ }^{89}$ and ISDA papers and reports were taken into consideration in the meetings of the Forum Group on Collateral..$^{90}$

Assisted by the Forum Group on Collateral, in June 2000 the European Commission issued a "Working Document on Collateral from the Commission to relevant bodies for consultation", which was accompanied by a first preliminary draft proposal for a directive on financial collateral arrangements. ${ }^{91}$ Rather than strengthening one approach or replacing both approaches with a sui generis statutory collateral interest, in the Working Document a twin-track approach was proposed that would remove legal uncertainty for both 'pledge collateral' arrangements and 'title transfer collateral' arrangements. ${ }^{92}$

In March 2001, the European Commission Proposal for a Financial Collateral Directive was transmitted to the European Parliament and the Council. ${ }^{93} \mathrm{~A}$ legally binding instrument was deemed necessary, as it was concluded that a solution building on a recommendation "would lack transparency and legal

\footnotetext{
88 The legal impediments identified in the ISDA Report were highlighted in the Subchapter 4.1.

89 See Keijser, op. cit. (fn. 6), p. 181.

$90 \quad$ E. g. the report "Collateral Arrangements in the European Financial Markets: the Need for Law Reform", prepared by ISDA in February 1999 and presented to the Giovannini Group in March 1999, was considered as a basis of discussion in the first meeting of the Forum Group on Collateral in October 1999. See: Financial Services Action Plan - Forum Group on the Cross-Border Use of Collateral, Issues Paper for the First Meeting of the Group, October 1999, p. 6 .

91 For a detailed review of the key questions addressed in the Working Document, see: Yeowart and Parsons, op. cit. (fn. 6), pp. 14-32.

92 See Murray, op. cit. (fn. 6), p. 303; Yeowart and Parsons, op. cit. (fn. 6), p. 16.

93 Proposal for a Directive of the European Parliament and of the Council on financial collateral arrangements, COM/2001/0168 final - COD 2001/0086 (OJ E 180, 26/6/2001); hereinafter: 'Proposal for a Financial Collateral Directive'.
} 
certainty for the market participants'. ${ }^{94}$ After an exceptionally quick co-decision process, ${ }^{95}$ the Financial Collateral Directive was adopted in June 2002.

\section{FINANCIAL COLLATERAL DIRECTIVE: MEETING THE NEEDS OF THE MARKET}

The industry's needs for legal change were met with the adoption of the Financial Collateral Directive, which brought on a full harmonization of substantive rules on the provision of collateral in financial collateral arrangements. As the harmonization efforts in the EU prior to the Financial Collateral Directive were orientated on mutual recognition and minimum harmonization, the focus of the Financial Collateral Directive on the full harmonization of substantive rules was considered to be a 'paradigm shift in Community legislation'. ${ }^{96}$

The objective of the Financial Collateral Directive was to create a minimum EU legal regime for the provision of financial collateral in bilateral financial collateral arrangements, and it was anticipated that the achievement of this objective "will contribute to the integration and cost-efficiency of the financial market as well as to the stability of the financial system in the Community, thereby supporting the freedom to provide services and the free movement of capital in the single market in financial services'. ${ }^{97}$ The creation of the minimum EU legal regime applicable to financial collateral arrangements was largely achieved through pointing up to the existing financial market practices, which were assessed as 'sound market practices', ${ }^{98}$ and binding the Member States to make changes in existing law in relation to the legal solutions which were perceived as burdens and unnecessary formalities, thus protecting the validity and enforceability of the financial collateral arrangements as they were envisaged and developed in the financial market practice. The level of reception

\footnotetext{
94 See Paragraph 2.3 of the Explanatory Memorandum to the Proposal for a Financial Collateral Directive.

95 The Council succeeded in reaching a common position only nine months after the initial proposal what is considered to be 'a remarkable fast birth giving not so frequent in EU legislative matters' (see Devos, D.: Legal Protection of Payment and Securities Settlement Systems and of Collateral Transactions in European Union Legislation, Seminar on Current Developments in Monetary and Financial Law - Law and Financial Stability, International Monetary Fund, Washington, 2006, p. 36). Cf. Löber, K. M.: The Developing EU Legal Framework for Clearing and Settlement of Financial Instruments, ECB Legal Working Paper Series, No. 1, 2006, p. 21.

96 See ibid. Cf. Vardi, op. cit. (fn. 6), p. 82.

97 See Recital (3) of the Financial Collateral Directive.

98 See $e$. g. recitals (5), (14) and (16) of the Financial Collateral Directive.
} 
of market-originated rules in the Financial Collateral Directive is so immense that it can be rightly said that 'the Commission effectively institutionalized pure market-based governance in this area'. ${ }^{99}$ Therefore, it does not come as a surprise that the Financial Collateral Directive is 'the only piece of EU legislation of which banks and their advisers are universally in favor'. ${ }^{100}$

Although narrow in its personal scope of application, ${ }^{101}$ the Financial Collateral Directive is rather broad in relation to its material scope of application. The financial collateral provided under financial collateral arrangement must consist of 'cash, financial instruments or credit claims' ${ }^{102}$ The market jargon term 'cash' is used to describe money credited to an account, while banknotes are explicitly excluded. ${ }^{103}$ The term 'financial instruments' is used with the intention to cover all debt and equities securities. ${ }^{104}$ 'Credit claims' ${ }^{105}$ were added

$99 \quad$ See Gabor and Ban, op. cit. (fn. 83), p. 623.

100 See Benjamin, op. cit. (fn. 6), p. 473.

101 The collateral provider and the collateral taker must each belong to one of the categories defined in the Article 1 (2) of the Financial Collateral Directive; e. g., public sector bodies, central banks and international financial institutions, supervised financial institutions, central counterparties, settlement agents and clearing houses (see: Article 1 (2) (a) - (d) of the Financial Collateral Directive). According to the Article 1 (2) (e) of the Financial Collateral Directive, financial collateral arrangements where one party is 'a person other than a natural person, including unincorporated firms and partnerships' (i. e. non-financial, commercial undertakings) are also covered, provided that the other party is an institution defined in the Article 1 (2) (a) - (d) of the Financial Collateral Directive. The Article 1 (3) of the Financial Collateral Directive reserves an option for a Member State to exclude the financial collateral arrangements with non-financial entities from the scope of the Financial Collateral Directive. This opt-out clause was used only by Austria. For personal scope of application of the Financial Collateral Directive, see Devos, op. cit. (fn. 95), pp. 39-40; Gretton, op. cit. (fn. 6), pp. 211-212; Löber, op. cit. (fn. 95), p. 22.

102 See Article 3 (4) (a) of the Financial Collateral Directive. Commodities, such as grain or precious metals, are not eligible as financial collateral under the Financial Collateral Directive (see: Keijser, op. cit. (fn. 6), p. 66).

103 See Recital (18) and the Article 2 (1) (d) of the Financial Collateral Directive.

104 In the Article 2 (1) (e) of the Financial Collateral Directive, 'financial instruments' are defined as 'shares in companies and other securities equivalent to shares in companies and bonds and other forms of debt instruments if these are negotiable on the capital market, and any other securities which are normally dealt in and which give the right to acquire any such shares, bonds or other securities by subscription, purchase or exchange or which give rise to a cash settlement (excluding instruments of payment), including units in collective investment undertakings, money market instruments and claims relating to or rights in or in respect of any of the foregoing'.

105 In the Article 2 (1) (o) of the Financial Collateral Directive, 'credit claims' are defined as 'pecuniary claims arising out of an agreement whereby a credit institution, as defined in Article 4(1) of Directive 2006/48/EC, including the institutions listed in Article 2 of that Directive, grants credit in the form of a loan'. 
as eligible financial collateral in 2009 through an amendment of the Financial Collateral Directive. ${ }^{106}$

The Financial Collateral Directive applies to financial collateral only if it has been provided, if that provision can be evidenced in writing, and if the financial collateral arrangement can be evidenced in writing or in a legally equivalent manner. ${ }^{107}$ The financial collateral being 'provided' means that financial collateral is 'delivered, transferred, held, registered or otherwise designated so as to be in the possession or under the control of the collateral taker or of a person acting on the collateral taker's behalf'. ${ }^{108}$ Thus, a specific type of a repurchase transaction known as 'hold-in-custody repo' or 'HIC repo', in which the seller retains the possession of the sold collateral although the legal title to collateral is transferred to the buyer, is not covered by the Financial Collateral Directive. ${ }^{109}$

The two types of financial collateral arrangements to which Financial Collateral Directive is to be applied are discussed in the Subchapter 5.1., while examples of the provisions of the Financial Collateral Directive which were influenced by the financial market practices are given in the Subchapter 5.2.

\subsection{ADOPTION OF THE TWIN-TRACK APPROACH}

Financial Collateral Directive has adopted the twin-track approach that was proposed by the financial market experts in order to remove legal uncertainty for both of the methods for provision of financial collateral. Thus, Financial Collateral Directive distinguishes two categories of financial collateral arran-

106 See Directive 2009/44/EC of the European Parliament and of the Council of 6 May 2009 amending Directive 98/26/EC on settlement finality in payment and securities settlement systems and Directive 2002/47/EC on financial collateral arrangements as regards linked systems and credit claims (OJ L 146, 10/6/2009).

107 See recitals (10) and (11), and the Article 1 (5) of the Financial Collateral Directive.

108 See Article 2 (2) of the Financial Collateral Directive. In the Recital (10) of the Financial Collateral Directive, it is clarified that 'only those financial collateral arrangements which provide for some form of dispossession' are covered by the Financial Collateral Directive. It is worth to note that the criterion requiring the collateral taker to be in 'possession' or 'control' of collateral, contained in the Article 2 (2) of the Financial Collateral Directive, has an autonomous meaning in EU law, as confirmed by the Court of Justice in Private Equity Insurance Group, C-156/15, EU:C:2016:851, paragraph 39. In this judgement, the Court held that the collateral taker may be regarded as having acquired 'possession or control' of collateral, in the form of monies lodged in an ordinary bank account, 'only if the collateral provider is prevented from disposing of them' (see: ibid., paragraph 44).

109 For HIC repo, see, e. g.: Fabozzi and Mann, op. cit. (fn. 36), p. 229. 
gements: (i) security financial collateral arrangements, and (ii) title transfer financial collateral arrangements. ${ }^{110}$

Financial Collateral Directive has introduced the notion of a 'security financial collateral arrangement' to designate the type of a financial collateral arrangement that employs the security interest method for provision of financial collateral, which was known in the market practice as 'pledge collateral arrangement'. A 'security financial collateral arrangement' means 'an arrangement under which a collateral provider provides financial collateral by way of security to or in favor of a collateral taker, and where the full or qualified ownership of, or full entitlement to, the financial collateral remains with the collateral provider when the security right is established'. ${ }^{111}$ The notion of security financial collateral arrangement covers any type of contractual security interest established over collateral, such as pledge, charge, and lien, where the collateral provider does not transfer the full legal title to collateral to the collateral taker.

'Title transfer financial collateral arrangement' is defined in the Financial Collateral Directive as 'an arrangement, including repurchase agreements, under which a collateral provider transfers full ownership of, or full entitlement to, financial collateral to a collateral taker for the purpose of securing or otherwise covering the performance of relevant financial obligations. ${ }^{112} \mathrm{Fi}-$ nancial collateral is not provided 'by way of security' as in security financial collateral arrangement, meaning that a security interest is not created in financial collateral under a title transfer financial collateral arrangement. The words 'securing or otherwise covering' are employed to describe the purpose of the collateral arrangement, not the method for provision of financial collateral. ${ }^{113}$

The transfer of 'full ownership' or 'full entitlement' to financial collateral is an outright transfer of title to financial collateral, meaning an unlimited transfer of all right, title and interest. ${ }^{114}$ This is especially evident in the case of repurchase transactions, which are a prime example of transactions employing title transfer collateral arrangements, where standard market do-

\footnotetext{
110 See Article 2 (1) (a) of the Financial Collateral Directive.

111 See Article 2 (1) (c) of the Financial Collateral Directive. For a justly criticism of the legislator's choice of the term 'ownership', see Gretton, op. cit. (fn. 6), p. 215.

112 See: Article 2 (1) (b) of the Financial Collateral Directive.

113 On the use of the words 'securing or otherwise covering', see, in particular: Murray, op. cit. (fn. 6), p. 286; Yeowart and Parsons, op. cit. (fn. 6), pp. 152-153.

114 However, it has been debated whether fiduciary transfers of title are also covered under the notion of title transfer financial collateral arrangements. Since a fiduciary transfer of title is essentially establishment of a security interest, it should not be regarded as a title transfer financial collateral arrangement. See, in detail: Keijser, op. cit. (fn. 6), pp. 160-162, 356-358.
} 
cumentation envisages an unlimited transfer of title as a method of providing financial collateral. ${ }^{115}$

\subsection{EXAMPLES OF THE PROVISIONS INFLUENCED BY THE MARKET PRACTICE}

\subsubsection{ENFORCEMENT OF SECURITY FINANCIAL COLLATERAL ARRANGEMENTS}

Recovery function of financial collateral in a security financial collateral arrangement is guaranteed by the provisions of Article 4 of the Financial Collateral Directive which deals with enforcement of security financial collateral arrangements. Member States are obliged to ensure that, in case of an event of default, the collateral taker is able to realize financial collateral by means of sale, appropriation or set off, in accordance with the terms of the security financial collateral arrangement, without being subject to additional formal requirements laid down in national law. ${ }^{116}$

\subsubsection{RIGHT OF USE OF FINANCIAL COLLATERAL}

As noted earlier in the Chapter 4, one of the main legal impediments to the efficient use of financial collateral in the European market, identified by the financial market participants, was the incompatibility of the security interest method for provision of collateral that was developed in the market practice, which combines a security interest with a collateral taker's general right of disposal of collateral, with the property law systems of Member States under which the provision of a general right of disposal on the basis of a security interest was not possible. In its set of principles that an effective and efficient modern legal regime for collateral arrangements should embody, ISDA proposed that the collateral taker 'should be free to deal with the collateral as though it were the outright owner of the assets'.117

Financial Collateral Directive has accepted this proposal and introduced a collateral taker's 'right of use' of financial collateral under a security financial

\footnotetext{
115 See supra in Subchapter 3.3.

116 See Article 4 (1) - (4) of the Financial Collateral Directive. On the 'liberal approach' of the Financial Collateral Directive in respect of enforcement of security financial collateral arrangements, see, in particular Keijser, op. cit. (fn. 6), pp. 279-290.
}

117 See ISDA Report, op. cit. (fn. 77), p. 11. 
collateral arrangement. ${ }^{118}$ The provisions of the Financial Collateral Directive relating to the 'right of use' apply only if the provided financial collateral consists of cash or financial instruments, but not of credit claims. ${ }^{119}$ The "right of use' is defined in the Article 2 (1) (m) of the Financial Collateral Directive as 'the right of the collateral taker to use and dispose of financial collateral provided under a security financial collateral arrangement as the owner of it in accordance with the terms of the security financial collateral arrangement'. Member States are obliged to ensure that the collateral taker is entitled to exercise a right of use, if and to the extent that the terms of a security financial collateral arrangement so provide. ${ }^{120}$

The right of use is the general right of disposal of financial collateral which entitles the collateral taker to use and dispose of the financial collateral as he deems fit, irrespective of whether there is an event of default or not. Thus, the tradability function of financial collateral is also guaranteed in security financial collateral arrangements. This purpose of the right of use is evident from the Recital (19) of the Financial Collateral Directive, where it is stated that the introduction of the right of use in case of security financial collateral arrangements 'increases liquidity in the financial market stemming from such reuse of 'pledged' securities'.

If the right of use has been exercised by the collateral taker, he is obliged to transfer equivalent collateral to the collateral provider at the latest at the end of the transaction when the secured financial obligations of the collateral taker become due, and the equivalent collateral is treated as if it has been provided at the same time that the original collateral was first provided. ${ }^{121}$ At the end of the transaction, alternatively to the provision of equivalent collateral, the collateral taker may, if and to the extent that the terms of a security financial collateral arrangement so provide, set off the value of the equivalent collateral against or apply it in the discharge of the financial obligations owed to him by collateral provider. ${ }^{122}$ If an event of default occurs while an obligation to transfer equivalent collateral remains outstanding, the obligation may be the subject of a close-out netting provision. ${ }^{123}$

118 On the controversial right of use established by the Financial Collateral Directive, see: Johansson, op. cit. (fn. 5), pp. 15-18; Keijser, op. cit. (fn. 6), pp. 177-185.

119 See Article 5 (6) of the Financial Collateral Directive.

120 See Article 5 (1) of the Financial Collateral Directive.

121 See Article 5 (2) and (3) of the Financial Collateral Directive.

122 See Article 5 (2) of the Financial Collateral Directive.

123 See Article 5 (5) of the Financial Collateral Directive. 
The provisions of Financial Collateral Directive on the collateral taker's right of use are not applied to title transfer financial collateral arrangements. Since under a title transfer financial collateral arrangement a full legal title to financial collateral is transferred to the collateral taker, there is no need to entitle the collateral taker with a special right of use of financial collateral. As a full legal owner of the financial collateral, the collateral taker may use and dispose of the financial collateral as he wishes, subject only to his contractual obligation to transfer the equivalent collateral to the collateral provider at the end of the transaction. Thus, both recovery and tradability functions of financial collateral are guaranteed under a title transfer financial collateral arrangement.

\subsubsection{ELIMINATING THE RISK OF RE-CHARACTERIZATION}

As discussed in Chapter 4, the risk of re-characterization of title transfer financial collateral arrangements as arrangements creating a security interest in financial collateral was the main concern to the financial market participants. Financial Collateral Directive requires that 'a title transfer financial collateral arrangement can take effect in accordance with its terms'. ${ }^{124}$ The purpose of this requirement is to eliminate the risk of re-characterization of title transfer financial collateral arrangements, and this aim of the Financial Collateral Directive is explicitly stated in the Recital (13) which states: 'This Directive seeks to protect the validity of financial collateral arrangements which are based upon the transfer of the full ownership of the financial collateral, such as by eliminating the so-called re-characterization of such financial collateral arrangements (including repurchase agreements) as security interests.'

\subsubsection{REMOVAL OF FORMAL REQUIREMENTS}

The financial market's need for a removal of cumbersome and impractical rules for creating, perfecting, maintaining and enforcing collateral arrangements was also met with the Financial Collateral Directive. The Article 3 (1) of the Financial Collateral Directive, which applies both to the title transfer financial collateral arrangements and the security financial collateral arrangements, provides for an obligation of Member States to 'not require that the creation, validity, perfection, enforceability or admissibility in evidence of a financial collateral arrangement or the provision of financial collateral under a financial collateral arrangement be dependent on the performance of any formal act'. A

${ }^{124}$ See Article 6 (1) of the Financial Collateral Directive. 
definition of a 'formal act' is not contained in the Financial Collateral Directive, but a non-exhaustive list of examples of such formal acts is given in the Recital (10). ${ }^{125}$

\subsubsection{RECOGNITION OF CLOSE-OUT NETTING}

Financial Collateral Directive seeks to protect the enforceability of bilateral close-out netting as a means of enforcement of title transfer financial collateral arrangements. To this end, the Article 6 (1) of the Financial Collateral Directive provides: 'If an enforcement event occurs while any obligation of the collateral taker to transfer equivalent collateral under a title transfer financial collateral arrangement remains outstanding, the obligation may be the subject of a close-out netting provision'. Moreover, Financial Collateral Directive aims at ensuring that both the security financial collateral arrangements and the title transfer financial collateral arrangements as a whole, as well as the close-out netting provisions contained in them, remain valid and enforceable notwithstanding the opening of insolvency proceedings against the collateral taker or collateral provider. ${ }^{126}$

125 Recital (10) of the Financial Collateral Directive regards as 'formal acts': 'the execution of any document in a specific form or in a particular manner, the making of any filing with an official or public body or registration in a public register, advertisement in a newspaper or journal, in an official register or publication or in any other matter, notification to a public officer or the provision of evidence in a particular form as to the date of execution of a document or instrument, the amount of the relevant financial obligations or any other matter'. On the other hand: 'acts required under the law of a Member State as conditions for transferring or creating a security interest on financial instruments, other than book entry securities, such as endorsement in the case of instruments to order, or recording on the issuer's register in the case of registered instruments, should not be considered as formal acts'.

126 Article 4 (5) of the Financial Collateral Directive deals generally with the financial collateral arrangements as a whole, and states that: 'Member States shall ensure that a financial collateral arrangement can take effect in accordance with its terms notwithstanding the commencement or continuation of winding-up proceedings or reorganisation measures in respect of the collateral provider or collateral taker'. Article 7 (1) (a) of the Financial Collateral Directive deals specifically with the close-out netting provisions contained in the financial collateral arrangements, and states that: 'Member States shall ensure that a close-out netting provision can take effect in accordance with its terms: (a) notwithstanding the commencement or continuation of winding-up proceedings or reorganisation measures in respect of the collateral provider and/or the collateral taker'. 


\subsubsection{DISAPPLICATION OF CERTAIN PROVISIONS OF INSOLVENCY LAW}

As noted earlier in Chapter 4, certain insolvency rules, such as the so-called 'zero-hour' rules and the preference rules ('suspect period' rules), were identified by the financial market participants as legal impediments to the efficient use of financial collateral in the European cross-border market. Financial Collateral Directive has obliged the Member States not to apply such rules to financial collateral arrangements, as these rules would inhibit the effective realization of financial collateral.

The Article 8 (1) (a) of the Financial Collateral Directive aims to protect the both types of financial collateral arrangements, as well as the provision of financial collateral under those arrangements, against the 'zero-hour' rules. Financial collateral arrangement, as well as the provision of financial collateral, 'may not be declared invalid or void or be reversed on the sole basis' that the financial collateral arrangement has come into existence, or the financial collateral has been provided 'on the day of the commencement of winding-up proceedings or reorganization measures, but prior to the order or decree making that commencement'. The same protection is extended in the Article 8 (2) of the Financial Collateral Directive to the financial collateral arrangement concluded, and the financial collateral provided, on the day of the insolvency but after the moment of the commencement of insolvency, provided that 'the collateral taker can prove that he was not aware, nor should have been aware, of the commencement of such proceedings or measures'.

In the same manner, the Article 8 (1) (b) of the Financial Collateral Directive aims to protect financial collateral arrangements and the provision of financial collateral under those arrangements against the 'suspect period' rules. ${ }^{127}$

Protection against the 'zero-hour' rules and 'suspect period' rules is also given to the market practices relating to margin transfers and substitution of collateral. ${ }^{128}$

127 Financial collateral arrangement, as well as the provision of financial collateral, 'may not be declared invalid or void or be reversed on the sole basis' that the financial collateral arrangement has come into existence, or the financial collateral has been provided 'in a prescribed period prior to, and defined by reference to, the commencement of such proceedings or measures or by reference to the making of any order or decree or the taking of any other action or occurrence of any other event in the course of such proceedings or measures'.

128 The Article 8 (3) of the Financial Collateral Directive provides: 'Where a financial collateral arrangement contains: (a) an obligation to provide financial collateral or additional financial collateral in order to take account of changes in the value of the financial collateral or in the amount of the relevant financial obligations, or (b) a right to withdraw financial collateral 


\section{CONCLUSION}

Financial Collateral Directive mirrors several of the contemporary tendencies relating to the change in the way legal rules are created and enforced and to the emergence of new, non-state legal actors.

In the field of law on financial collateral, the legal rules relating to creation and enforcement of the financial collateral arrangements had originated in the financial market practice. These legal rules were developed by financial market participants themselves since the traditional legal rules contained in the state law did not offer solutions that would be suitable for achieving the aims of the market participants when entering into various new types of transactions in rapidly growing transnational financial markets. International financial market associations played a key role in harmonizing the market-originated rules, codifying them in the standard market documentation and making them customary through the promotion of the standard market documentation. The widely used standard market master agreements are a prime example of a private regulation effectuated through contract.

Since the new legal structures for provision of financial collateral were created in the financial market because the traditional legal structures which existed in the national law were not appropriate for realization of the economic results intended by the parties to collateralized transactions, they inevitably came at odds with the state-originated legal rules to which the market-developed legal structures were unfamiliar. The classic rules of property law of the European countries presented obstacles to creating and perfecting financial collateral arrangements, the legal rules of insolvency law of the European countries contained restrictions on enforcement of financial collateral arrangements, while a tendency existed to re-characterize the market-originated structures as the more familiar traditional legal structures. Additionally, to trade efficiently in the European cross-border market, the market participants had to take into

on providing, by way of substitution or exchange, financial collateral of substantially the same value, Member States shall ensure that the provision of financial collateral, additional financial collateral or substitute or replacement financial collateral under such an obligation or right shall not be treated as invalid or reversed or declared void on the sole basis that: (i) such provision was made on the day of the commencement of winding-up proceedings or reorganisation measures, but prior to the order or decree making that commencement or in a prescribed period prior to, and defined by reference to, the commencement of winding-up proceedings or reorganisation measures or by reference to the making of any order or decree or the taking of any other action or occurrence of any other event in the course of such proceedings or measures; and/or (ii) the relevant financial obligations were incurred prior to the date of the provision of the financial collateral, additional financial collateral or substitute or replacement financial collateral.' 
account all the different legal rules contained in the non-harmonized national laws of the European countries.

The international financial market associations became crucial proponents of the reform of law pertaining to financial collateral in the European Union. The idea of a harmonized EU law on financial collateral fit well with the European Union's intention to create a single financial market. The alignment of the objectives of the European Union and of the financial market participants created the opportunity for a change in law.

The legislative process leading to the adoption of Financial Collateral Directive is characterized by the strong involvement of the representatives of the financial market who actively contributed to the shaping of the legal solutions contained in the Financial Collateral Directive. The significant reception of the practices developed in the financial market is visible in the terminology used, in the legal structures employed, and in the policy choices expressed in the provisions of the Financial Collateral Directive.

\section{LITERATURE}

1. Benjamin, J.: Financial Law, Oxford University Press, Oxford - New York, 2007.

2. Choudhry, M.: The Repo Handbook, Butterworth-Heinemann, Oxford, 2010.

3. Collins, H.: Flipping Wreck: Lex Mercatoria on the Shoals of Ius Cogens, in Grundmann, S., Möslein, F. and Riesenhuber, K. (eds.), Contract Governance - Dimensions in Law and Interdisciplinary Research, Oxford University Press, Oxford, 2015.

-DOI: https://doi.org/10.1093/acprof:oso/9780198723202.003.0023

4. Comotto, R.: Haircuts and Initial Margins in the Repo Market, ICMA European Repo Council, Zurich, 2012.

5. Comotto, R.: The European Repo Market, in Fabozzi, F. J. and Mann, S. V. (eds.), Securities Finance - Securities Lending and Repurchase Agreements, John Wiley \& Sons, Hoboken, 2005.

6. Cuniberti, G.: Three Theories of Lex Mercatoria, Columbia Journal of Transnational Law, 52 (2), 2014.

7. Devos, D.: Legal Protection of Payment and Securities Settlement Systems and of Collateral Transactions in European Union Legislation, Seminar on Current Developments in Monetary and Financial Law - Law and Financial Stability, International Monetary Fund, Washington, 2006.

8. Fabozzi, F. J., Mann, S. V.: Repurchase and Reverse Repurchase Agreements, in Fabozzi, F. J. and Mann, S. V. (eds.), Securities Finance - Securities Lending and Repurchase Agreements, John Wiley \& Sons, Hoboken, 2005. 
9. Gabor, D., Ban, C.: Banking on Bonds: The New Links Between States and Markets, Journal of Common Market Studies, 54 (3), 2016.

-DOI: https://doi.org/10.1111/jcms.12309

10. Gretton, G. L.: Financial Collateral and the Fundamentals of Secured Transactions, Edinburgh Law Review, 10 (2), 2008.

-DOI: https://doi.org/10.3366/elr.2006.10.2.209

11. Haentjens, M., de Gioia-Carabellese, P.: European Banking and Financial Law, Routledge, London - New York, 2015.

12. Johansson, E.: Property Rights in Investment Securities and the Doctrine of Specificity, Springer, Berlin - Heidelberg, 2009.

-DOI: https://doi.org/10.1007/978-3-540-85904-8

13. Keijser, T. R. M. P.: Financial Collateral Arrangements, Kluwer, Deventer, 2006.

14. Lomnicka, E.: Financing Devices Involving the Transfer or Retention of Title, in Beale, H., Bridge, M., Gullifer, L., Lomnicka, E., The Law of Security and Title-Based Financing, Oxford University Press, Oxford, 2012.

15. Löber, K. M.: The Developing EU Legal Framework for Clearing and Settlement of Financial Instruments, ECB Legal Working Paper Series, No. 1, 2006.

16. Murray, E.: Financial collateral arrangements and the financial markets, in Dahan, F. (ed.), Research Handbook on Secured Financing in Commercial Transactions, Edward Elgar Publishing, Cheltenham - Northampton, 2015.

-DOI: https://doi.org/10.4337/9781781001844.00020

17. Schindler, C., Hindelang, M.: Praxishandbuch Repos und Wertpapierdarlehen, Springer Gabler, Wiesbaden, 2016.

-DOI: https://doi.org/10.1007/978-3-8349-4023-0

18. Stadler, V., Lanoo, K.: The EU Repo Markets: The Need for Full Integration, Centre for European Policy Studies, Brussels, 2000.

19. Vardi, N.: The Integration of European Financial Markets, Routledge-Cavendish, London - New York, 2011.

20. Yeowart, G., Parsons, R., Murray, E., Patrick, H.: Yeowart and Parsons on the Law of Financial Collateral, Edward Elgar Publishing, Cheltenham - Northampton, 2016.

21. Zimmermann, C. D.: A Contemporary Concept of Monetary Sovereignty, Oxford University Press, Oxford, 2013.

-DOI: https://doi.org/10.1093/acprof:oso/9780199680740.001.0001

\section{LEGISLATION}

1. Directive 2002/47/EC of the European Parliament and of the Council of 6 June 2002 on financial collateral arrangements (OJ L 168, 27/6/2002) 
2. Directive 2009/44/EC of the European Parliament and of the Council of 6 May 2009 amending Directive 98/26/EC on settlement finality in payment and securities settlement systems and Directive 2002/47/EC on financial collateral arrangements as regards linked systems and credit claims (OJ L 146, 10/6/2009)

3. Regulation (EU) $2015 / 2365$ of the European Parliament and of the Council of 25 November 2015 on transparency of securities financing transactions and of reuse and amending Regulation (EU) No 648/2012 (OJ L 337, 23/12/2015)

4. Communication from the Commission - Implementing the Framework for Financial Markets: Action Plan, COM (1999) 232 final (11/5/1999)

5. Financial Services Action Plan - Forum Group on the Cross-Border Use of Collateral, Issues Paper for the First Meeting of the Group (October 1999)

6. Proposal for a Directive of the European Parliament and of the Council on financial collateral arrangements, COM/2001/0168 final - COD 2001/0086 (OJ E 180, 26/6/2001)

\section{CASES}

1. Court of Justice, Private Equity Insurance Group, C-156/15, EU:C:2016:851

\section{OTHER SOURCES}

1. International Capital Market Association - European Repo and Collateral Council, A Guide to Best Practice in the European Repo Market, International Capital Market Association, Zurich, 2017

2. International Capital Market Association, European Repo Market Survey - Number 32 - Conducted December 2016, International Capital Market Association, Zurich, 2017

3. International Securities Lending Association, ISLA Securities Lending Market Report - 6th Edition - December 2016, International Securities Lending Association, London, 2016

4. International Swaps and Derivatives Association, Collateral Arrangements in the European Financial Markets - The Need for National Law Reform, International Swaps and Derivatives Association, London, 2000

5. International Swaps and Derivatives Association, Credit Risk and Regulatory Capital, International Swaps and Derivatives Association, 1998

6. International Swaps and Derivatives Association, Guidelines for Collateral Practitioners, International Swaps and Derivatives Association, 1998

7. International Swaps and Derivatives Association, ISDA 1999 Collateral Review, International Swaps and Derivatives Association, 1999 